\title{
What Might Drive Block Ownership In Canadian Firms? Evidence Through Count Data Models
}

Malek Saihi, Faculty of Economics and Management of Tunis, Tunisia Amel Belanes, High Institute of Management of Tunis, Tunisia

\begin{abstract}
This paper addresses the following crucial question: What might influence the decision of a blockholder to enter or exit a firm? Within a concentrated ownership context, such as Canada, we investigate impact of corporate governance, firm's risk, debt, liquidity and size on increase in number of blockholders. This study contributes to research topic by shedding light on endogeneity and dynamic nature of ownership structure. In order to take into account discreteness of additional blockholders' number, we used four Count Data models, namely Poisson, Negative Binomial, Zero-Inflated Poisson, and Zero-Inflated Negative Binomial models. Our findings show that while excessive high level of risk, free cash-flow, firm size, institutional and insiders' ownership dissuade shareholders from getting large stakes, moderately high levels of risk and firm leverage encourage them to join Blockholders' list.
\end{abstract}

Keywords: Corporate governance; Blockholders; Count Data regressions; Canada

\section{INTRODUCTION}

hat is the role of blockholders? How prevalent are they? What corporate decisions may they affect? All of these questions have long been debated (Jensen and Meckling, 1976; Demsetz, 1983; Holderness and Sheehan, 1988). A large body of previous research has highlighted role of blockholders and their influence on various firm decisions. The conventional wisdom that blockholders can exercise significant voting power predicts their ability to control firms' management and to shape their decisions. Blockholders are also recognized to have potential to limit agency problems and hence to improve firm performance. Because of relevance of invested resources, they have all interest and power to monitor firms' strategies and to ensure insider responsiveness (Shleifer and Vishny, 1986; Barclay and Holderness, 1989). Most studies have been, however, limited by an implicit assumption that ownership concentration has an immediate impact on firm decisions.

This study contributes to research topic by shedding light on endogeneity and dynamic nature of ownership structure. There is no consensus regarding potential effect of firms' characteristics on ownership concentration. The initial argument is first formulated by Demsetz (1983) who argues that ownership structure is an endogeneous outcome of decisions based on a profit maximizing calculation. Ownership concentration should vary systematically across firms depending on their characteristics. Some factors that determine performance, such as firm size, firm risk, liquidity, industry classification, corporate governance and investor protection; likely influence ownership structure. Feedback effect of firm's characteristics on ownership has increasingly been recognized (Baozhi, 2004; $\mathrm{Hu}$ and Izumida, 2008). However, this effect depends on location, firm-specific economic variables, country characteristics, special local laws, and governance practices. For instance, empirical findings often emphasize a non significant effect of performance on ownership concentration in dispersed-ownership contexts where investors are market-oriented, such as US (Demsetz and Lehn, 1985). We expect different results when research is carried on in a concentrated-ownership economy, such as Canada. Canadian firms are renowned to be much more concentrated than their American and British counterparts (La Porta et al., 1999; Morck et al., 2000). Most of Canadian listed 
firms have shareholders with stakes of $20 \%$ or higher (Gadhoum, 2006). Their percentage is around 60\%; it can be even higher because of regional disparities across provinces; for instance, more than $80 \%$ for Quebec firms (Bozec and Laurin, 2008). But above all, economic power is often concentrated in hands of single influential elite (Naylor, 1975; Francis, 2008). According to Morck et al. (2000), concentration of ownership might be due to lower productivity growth. Recently, ownership concentration extent has amazingly decreased in Canada. When compared to prior research, cut-off level of $20 \%$ has declined from $60 \%$ to $41 \%$ of Canadian listed firms between 1996 and 2007 (Valsan, 2007). Earlier studies have explained such a decline mainly by making reference to legal, political, geographic, cultural, and actually institutional and corporate governance factors. Although one can think of broad issues concerning ownership concentration, it is an open question: what might influence block ownership? Empirical studies focus little, if any, attention on effect of firm characteristics on block ownership, let alone on blockholders number. This paper addresses the following crucial question: what might influence the decision of a blockholder to enter or exit a firm? Within a concentrated ownership context, such as Canada, we investigate impact of corporate governance, firm's risk, debt, liquidity and size on increase in number of blockholders.

The remainder of paper is organized as follows. Section 2 reviews related literature and develops our hypotheses. Section 3 presents data and describes research methodology. Section 4 summarizes and discusses empirical results. A conclusion follows with implications and suggestions for future research.

\section{LITERATURE REVIEW AND HYPOTHESES}

There is a wide recognition that ownership concentration has a profound impact on firm characteristics. Conversely, effect of latter on change in block ownership is not well explored. Berle and Means (1932) are the first to raise explicitly issue of relationship between corporate ownership and performance. According to them, a more diffuse ownership breaks link between ownership and control; maximization of profits is thus no longer guaranteed. This position is first challenged by Demsetz (1983) and later by Demsetz and Lehn (1985) who focus on investor decision about shareholding. Choice between dispersed and concentrated ownership is a rational decision influenced by profit-maximizing interests. Large block ownership is motivated by two main factors: shared benefits of control and private benefits of control which are not mutually exclusive. Besides, stability of block ownership mainly stems from prominent role of large shareholders. In fact, as long as large shareholders are constantly monitoring firm management, block ownership is expected to be stable (Shleifer and Vishny, 1986). Whatever they are independent or sit on board of directors, large blockholders almost remain in firm for at least five years (Barclay and Holderness, 1989; Denis and Sarin, 1999). However, willingness of blockholders to enter or exit a firm depends on corporate and ownership characteristics of firm as well as its financial and accounting specificities. Subsequent to seminal work of Grossman and Hart (1980), academic literature has reported that large shareholders are tempted to extract higher private benefits of control when their stakes exceed a specific threshold (Barclay and Holderness, 1989). They would use their voting power to consume corporate resources or to solely siphon off private benefits. Therefore, if blockholders are prone to take out value, they are inclined to enlarge their stock ownership in firms that have performed well to gain more control (Hu and Izumida, 2008). According to rent-protection hypothesis developed by Bebchuk (1999), to the extent that private benefits of control are high, blockholders likely increase their shares to preserve such benefits and avoid control grab. In fact, when private benefits are large enough and control is valuable enough, leaving control up would appeal to rivals who seek to capture these private benefits. It makes it appropriate to maintain a lock on control by increasing ones stock ownership (Bebchuk, 1999). Beyond this brief review of literature, willingness of shareholders to detain large stakes is driven by their ability to drain and safeguard shared and private benefits of control. Therefore, their decision to acquire diversified or concentrated shareholding depends on both firm ownership structure and its financial characteristics.

\subsection{Ownership structure and blockholding}

Institutional investors might act as a substitute for blockholders as a monitoring force. They have indeed opportunity to alleviate agency problems and guarantee achievement of all shareholders' interests (Grossman and Hart, 1980; McConnell and Servaes, 1990). They are commonly recognized to have material resources, sophisticated skills and highly-developed competences to control firm management. Likewise, institutional investors can compel not only firm manager but also other shareholders, namely blockholders, to focus more on corporate performance and less on opportunistic or self-behavior. Actually, Institutional investors have become increasingly 
active in corporate governance, especially in underperforming firms (Gillan and Starks, 2007). Large shareholders are thus more monitored given dominant presence of institutional investors; and hence less inclined to extract private benefits and to enlarge their stakes. Therefore, it is expected that:

Hypothesis 1. The higher is institutional ownership, the lesser is number of blockholders.

In the same vein, it should be less easy for blockholders to interfere in management of firms with large insiders' ownership. They cannot easily amass private benefits. On one hand, insiders can achieve absolute control of firms and become more powerful in monitoring firm management (McConnell and Servaes, 1990). On the other hand, by acquiring too large stakes, insiders are tempted to entrench themselves and to take out potential benefits at the expense of outside shareholders (Grossman and Hart, 1980). Blockholders become hence no longer tempted to increase their shareholding as they cannot afford private benefits. Thus, we suggest testing the following hypothesis:

Hypothesis 2. Insider shareholding has negative influence on number of blockholders.

\subsection{Firm financial characteristics and blockholding}

Modern financial theory, mainly Capital Asset Pricing Model and Arbitrage Pricing Theory, provides support to positive influence of risk on performance (Sharpe, 1964; Lintner, 1965; Ross, 1976). Shareholders should be appealed to risky firms in order to extract higher returns. Besides, from an entrepreneurial perspective, risky projects are associated with efforts to create, to innovate, to develop and to take on new opportunities of investment and growth (Bowman 1980; Miller and Bromiley, 1990). Firm performance cannot be promoted unless we devote such efforts. Shareholders are hence expected to increase their ownership so as to enjoy larger benefits; but above all to cope with potential down side of risk. In fact, as level of risk gets higher, they should hold larger stakes in order to better monitor firm management and remain in full control (Demsetz, 1983; Demsetz and Lehn, 1985). Perhaps, thanks to their control rights, only large shareholders can bear cost of information collecting and have a greater incentive for monitoring than directors, who may have little or no wealth invested in firm (Shleifer and Vishny 1986). Even though blockholder can sell his shares whenever they become risky, it would be appropriate to hold them because their price will be very low and no longer worthy (Hu and Izumida, 2008). Our third hypothesis can be hence formulated as follows:

Hypothesis 3a. The riskier is the firm, the higher is number of blockholders.

However, portfolio selection related literature presumes that investors should hold diversified portfolios when firms risk increases so as to eliminate at least diversifiable risk (Markowitz, 1952; Merton, 1972). In fact, blockholders investing most of their wealth in a single firm are likely more averse to risky projects than atomistic shareholders with widely spread ownership. Their incentives to diversify their portfolios might be stronger when the risk they bear is high. For instance, whenever investors believe that their shares are highly risky and that their prices exceed their intrinsic values, they might almost sell them to diversify their personal portfolio and escape risk costs (Hu and Izumida, 2008). Therefore, safeguarding ones private benefits is costly as a concentrated stock ownership is rather not well diversified; and it is expected that:

Hypothesis 3b. High levels of risk reduce number of blockholders.

Additionally, under the assumption of free cash flow hypothesis of Jensen (1986), debt is viewed as a hard claim that helps to alleviate agency problems. Indeed, firm leverage reduces agency cost of free cash flow; what ensures convergence of stakeholders' interests. Creditors may be alternative monitors, who provide some control on management (Jensen and Meckling, 1976; Stulz, 1990; Hart and Moore, 1995). Therefore, blockholders cannot easily accrue private benefits. They are even prone to forgo these benefits if need for external financing to fund growth opportunities is greater (Mueller, 2008). Blockholders are no longer inclined to enlarge their shareholding in levered firms. Consequently, number of blockholders is likely to decrease with rise of firm leverage; and we advocate checking the following hypothesis:

Hypothesis 4. Debt has negative impact on number of blockholders. 
Like the aforementioned negative influence of debt on private benefits, and consequently on block ownership, a similar effect of free cash flow is recognized. In fact, adverse selection hypothesis posits that when informed shareholders possess superior information; an information asymmetry arises, which reduces liquidity (Grossman and Stiglitz, 1980; Glosten and Milgrom, 1985). That is a low level of liquidity is associated with presence of few shareholders that possess, analyze, and trade on information (Black, 1992; Hartzel and Starks, 2003). In addition to insiders and institutions, blockholders are agreed to have superior information (McConnell and Servaes, 1990; Bethel et al., 1998). Consequently, blockholders in such firms can provide control management and protect their shareholdings. Conversely, when level of free cash flow is so high, there are acute agency problems and interests conflicts. These firms are hard to monitor; which dissuade blockholders to invest larger stakes in them. Thus, we suggest testing the following hypothesis:

\section{Hypothesis 5. Free cash flow has negative influence on number of blockholders.}

\section{DATA AND METHODOLOGY}

\subsection{Data and sample}

Firms were selected from publicly traded companies in Toronto Stock Exchange between 2008 and 2010. We applied simple random sampling method in order to make up a representative sample and derive reliable results. Moreover, selected firms should satisfy various requirements; for instance availability of ownership data as well as complete accounting and financial information. Final sample consists of 156 Canadian listed firms over the period 2008-2010. Financial and accounting data were extracted from "World Scope" database, while ownership data were drawn from firms' proxy circulars. We also used Website of Toronto Stock Exchange (TSX) to add-on missing data. We yearly counted increase in number of blockholders. This is the dependent variable of our models. Canadian regulations require insiders to disclose holdings "beneficially owned, directly or indirectly, or exercised control or direction" exceeding $10 \%$ of a firm's shares. Therefore, we define as a blockholder the shareholder who detains at least $10 \%$ of total shares. Variable ADBHNB sets for number of additional blockholder. To test impact of corporate governance on number of additional blockholders, we consider ownership of both insiders and institutional investors. Likewise, we exclude insiders and institutional investors from definition of blockholder in order to avoid multi-collinearity problem. We define insiders' ownership as proportion of shares held by managers and board directors. Institutional ownership includes holdings of institutional investors. Institutional investors are banks, insurance companies, mutual funds and pension funds, according to Security Rule. Similarly, we account for some financial characteristics of firms that are theoretically approved to affect ownership structure and hence block ownership. We take account of level of firm liquidity through free cash flow variable. We test influence of firm's risk level. We use BETA variable, systematic risk, which is computed by applying Capital Asset Pricing Model. Effect of financial structure is captured through DEBT variable; that is debt-to-equity ratio. We also add CAPEX variable to proxy for firms' growth opportunities. CAPEX variable is measured by capital expenditures to total assets ratio. We finally control for size effect using LnASSETS variable; that is total assets on a log scale.

\subsection{Econometric modeling}

Number of additional blockholders can take only integer values. Discrete nature of our dependent variable does not comply with linear regression models' requirements, since assumption of residuals' normality is not satisfied (Cincera, 1997). Poisson regression is commonly advanced as a solution to encounter discreteness of dependant variable (Landry, Amara and Saihi, 2007). In order to fulfill with requirements of this regression and of all count data specifications, which deal only with positive integer values, we censored negative outcomes, which compute a decline in number of blockholders. Under this first count data specification, number of additional blockholders ( $\mathrm{Y}$ ) is supposed to match with Poisson distribution like follows:

$\operatorname{prob}\left(\mathrm{y}_{\mathrm{i}} \mid \lambda_{\mathrm{i}}\right)=\frac{\exp \left(-\lambda_{\mathrm{i}}\right) \lambda_{\mathrm{i}}^{\mathrm{y}_{\mathrm{i}}}}{\mathrm{y}_{\mathrm{i}} !} ;$ with $\mathrm{E}(\mathrm{Y})=\operatorname{Var}(\mathrm{Y})=\lambda$

According to Faria et al. (2003), Poisson regression links $\lambda$ parameter with set $X$ of independent variables, and vector $\beta$ of parameters to be estimated, through this equation: $\ln (\lambda)=X \beta$. 
When equality between mean and variance of dependant variable is rejected, Poisson model turns out to be no more valid and Negative Binomial model, our second count data model, becomes more relevant (Landry, Amara and Saihi, 2007). Under latter model, two first moments are governed by these equations: $\mathrm{E}(\mathrm{Y} \mid \mathrm{X}, \beta)=\lambda ; \operatorname{Var}(\mathrm{Y} \mid \mathrm{X}, \beta)=\lambda(1+\alpha \lambda)$

Over-dispersion intensity is captured through $\alpha$ parameter (Faria et al., 2003). Table 2 carries doubts about presence of over-dispersion problem for dependent variable (ADBHNB), since its mean of 0.47 is quite close to its variance of 0.59 (standard deviation of 0.77). However, as suggested by Cameron and Trivedi (1998), we should perform recommended over-dispersion statistical test in order to check presence of significant Alpha $\alpha$ parameter. Beyond over-dispersion problem, while dealing with count data, we should verify presence of zero-inflation problem. Due to financial constraints and ambiguity about firms' future performances, shareholders do not always acquire large stakes of shares. Consequently, zero is a common value for dependant variable. This fact is confirmed by descriptive statistics. Indeed, after censoring negative values, $65.9 \%$ of sample companies did not attract any additional blockholder over research period. When number of zeros reported for dependant variable is not complying with expected numbers under Poisson and Negative Binomial distributions, recourse to zero-inflated models becomes mandatory (Yip and Yau, 2005). Hence, we should test two additional models: Zero-Inflated Poisson and Zero-Inflated Negative Binomial models. Later, we will rely on Vuong Statistic to decide which specification matches with data. According to Long (1997), large positive values of this Statistic recommend use of Zero-inflated specification, large negative values support standard specification, while values around zero place us in an intermediate case.

\section{RESULTS AND DISCUSSIONS}

\subsection{A survey of number of blockholders}

Table 1 summarizes distribution frequencies for change in number of additional blockholders during 20082010. Results indicate that number of blockholders have increased for $24.4 \%$ of Canadian firms, decreased for $28.3 \%$ of them, and remain stable for around $47.2 \%$ of them. Increase in number of blockholders varies from one to four. $17.9 \%$ of firms have an only new blockholder while $4.1 \%, 2.1 \%$ and $0.3 \%$ of them have respectively two, three and four additional large shareholders. Such a result puts in evidence that it is not so easy to convince a shareholder to invest so much in a unique firm even though he will become a blockholder who is able to monitor and control firm management. According to portfolio selection theory, shareholders are likely to bear higher levels of risk whenever they concentrate most of their wealth in a single investment. Willingness to enter or to exit a firm is a rationale decision that is influenced by trade-off between profits and costs.

Table 1. Distribution frequencies for dependent variable (ADBHNB)

\begin{tabular}{|c|c|c|c|c|c|c|}
\hline & Censored negative values & $\mathbf{0}$ & 1 & 2 & 3 & 4 \\
\hline ADBHNB (before censoring) & $28.3 \%$ & $47.2 \%$ & $17.9 \%$ & $4.1 \%$ & $2.1 \%$ & $0.3 \%$ \\
\hline ADBHNB (after censoring) & - & $65.9 \%$ & $25.0 \%$ & $5.8 \%$ & $2.9 \%$ & $0.5 \%$ \\
\hline
\end{tabular}

ADBHNB: number of additional blockholders.

Descriptive statistics of number of additional blockholders are presented in Table 2. Correlation analysis provides us with a preliminary idea about potential factors that might influence increase in number of blockholders. These determinants likely include firm risk, leverage, liquidity, size, capital expenditure; as well as ownership of insiders and institutional investors. Parametric correlations between climb of blockholders number and these potential determinants are reported in Table 2 .

Table 2. Parametric correlations and descriptive statistics for dependent variable

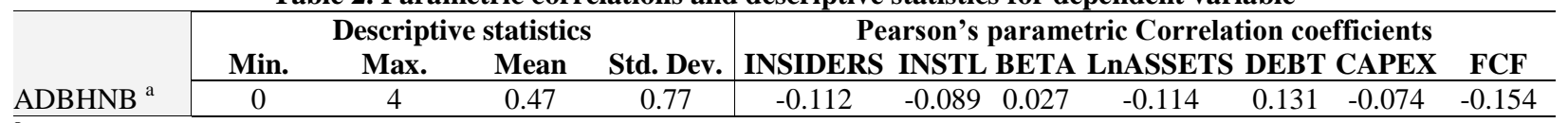

${ }^{a}$ Descriptive statistics and parametric correlations apply for ADBHNB after censoring of negative values; ADBHNB: number of additional blockholders; INSIDERS: insiders' ownership; INSTL: institutional ownership; BETA: systematic risk; DEBT: debtto-equity ratio; CAPEX: capital expenditures to total assets ratio; LnASSETS: $\log$ (total assets). 
This first investigation reveals that number of additional blockholders is positively related to firm risk and leverage but negatively with all other factors. For instance, large shareholders are inclined to invest in riskier firms which are believed to have higher performance; which allows them to extract larger benefits. Similarly, blockholders are appealed to levered firms which have lower equity ratios; entailing inflation of their voting power. However, presence of potential rivals such as insiders or institutional shareholders would deter blockholders to enter a firm. Similarly, bigger firms and those with higher levels of either free cash flow or capital expenditures have greater agency conflicts and are less easy to monitor. Blockholders are therefore less prone to invest in such firms.

\subsection{Ownership structure and firm financial characteristics analysis}

Table 3 reports descriptive statistics and parametric correlations for independent variables which proxy for ownership of insiders and institutional investors; as well as some firm financial characteristics. Descriptive statistics highlight dominance of insiders in Canadian stock exchange. Directors and managers hold on average $22.15 \%$ of total ownership rights in firms. Insiders' ownership has even reached $57.14 \%$ in some Canadian firms. Such a result provides support to the fact that Canadian firms are widely renowned to be highly concentrated (Morck et al., 2000; Gadhoum, 2006; Bozec and Laurin, 2008). But above all, such a result might imply that insiders exert a great role in firms monitoring; especially when compared with institutional ownership. Institutional ownership is around $9.61 \%$ which is on average much less than insiders' ownership.

Table 3. Parametric correlations and descriptive statistics for independent variables

\begin{tabular}{l|cccc|cccccc}
\hline & \multicolumn{3}{|c|}{ Descriptive statistics } & \multicolumn{7}{c}{ Pearson's parametric Correlation coefficients } \\
& Min. & Max. & Mean & Std. Dev. & INSIDERS & INSTL & BETA & LnASSETS & DEBT CAPEX \\
INSIDERS (\%) & 6.25 & 57.14 & 22.15 & 11.86 & 1 & & & & & \\
INSTL (\%) & 0.12 & 90.03 & 9.61 & 9.84 & 0.163 & 1 & & & \\
BETA & -0.38 & 3.38 & 0.98 & 0.48 & 0.133 & 0.118 & 1 & & \\
LnASSETS a $_{\text {DEBT }}$ & 6.10 & 12.40 & 8.50 & 1.21 & -0.146 & -0.119 & -0.052 & 1 & & \\
CAPEX & 0.00 & 24.91 & 1.16 & 2.11 & -0.044 & -0.365 & -0.024 & 0.024 & 1 & \\
FCF $^{\text {b }}$ & 0.01 & 0.30 & 0.05 & 0.04 & -0.053 & -0.053 & 0.104 & 0.096 & -0.017 & 1 \\
\hline
\end{tabular}

a Before logarithmic transformation, Assets are measured in thousands of CAD; ${ }^{\mathbf{b}}$ Free cash flow are in thousands of CAD; ADBHNB: number of additional blockholders; INSIDERS: insiders' ownership; INSTL: institutional ownership; BETA: systematic risk; DEBT: debt-to-equity ratio; CAPEX : capital expenditures to total assets ratio; LnASSETS: $\log$ (total assets).

Table 3 shows an overall firms' systematic risk (Beta) close to 0.98 ; which pleads for representativeness of sample. Some Canadian listed firms are highly levered with a debt-to-equity ratio reaching 24.91. However, average debt-to-equity ratio is around 1.16; which is quite moderate. Impact of leverage on scope of moral hazard and on discretionary power of shareholders is confusing. On one hand, it may increase voting power of controlling party; and hence interests conflicts (Harris and Raviv, 1988; Stulz, 1990). On the other hand, it may reduce agency costs and serves as a disciplinary mechanism (Fama, 1980; Jensen, 1986). Our data also show that level of liquidity broadly varies across Canadian firms with an average of 279.38 thousands Canadian dollars. Ratio of capital expenditures to total assets is around 0.05 with a maximum of 0.30 . These investments are approved to be discretionary and not easily monitored. This preliminary descriptive analysis suggests that Canadian firms are highly concentrated with a potential high level of agency costs. Willingness of large shareholders to invest in Canadian firms is thus expected to be very low. There is often only one and scarcely four additional blockholders, for the whole period. Such a result was already reported in Table 1. In addition to descriptive statistics of dependent variables, we test parametric correlations between them. Results are summarized in Table 3. The highest reported correlation coefficient of 0.241 is far below critical threshold of 0.75 . Such findings reject presence of any multicollinearity problem; and provide reliability for our future results.

\subsection{Determinants of increase in blockholders number}

Four Count Data models were applied to explain increase in number of blockholders, namely Poisson model, Negative Binomial model, Zero-Inflated Poisson model, and Zero-Inflated Negative Binomial model. As already explained, discreteness of investigated variable compels us to apply count data models. Table 4 summarizes results of these regressions. Results of Poisson model, Negative Binomial model, Zero-Inflated Poisson model, and 
Zero-Inflated Negative Binomial model are respectively reported in Panel A, Panel B, Panel C and Panel D. All regression models are significant at $1 \%$ threshold. Quality of data adjustment ranges between $8.38 \%$ and $10.68 \%$; which is quite reasonable for count data models. Alpha over-dispersion parameters are positive but not significant; which approves of reliability of both Poisson and Zero-Inflated Poisson models; but not systematically rejects validity of Negative Binomial and Zero-Inflated Negative Binomial models. Besides, Vuong Statistic, comparing standard and Zero-Inflated specifications, does not reach very high levels, especially while comparing Poisson and Zero-Inflated Poisson models. The four count data models are hence valid; and we should consider all of them. Empirical findings reveal that the four models almost lead to same conclusions; which pleads for analysis robustness and reliability.

Table 4. Poisson (Panel A), Negative Binomial (Panel B), Zero-Inflated Poisson (Panel C), and Zero-Inflated Negative Binomial (Panel D) regressions' results with number of Additional Blockholders (BHNB) as dependent variable.

\begin{tabular}{|c|c|c|c|c|c|c|c|c|}
\hline \multirow[b]{2}{*}{ Independent variables } & \multicolumn{2}{|c|}{ Panel A: Poisson } & \multicolumn{2}{|c|}{$\begin{array}{c}\text { Panel B: Negative } \\
\text { Binomial }\end{array}$} & \multicolumn{2}{|c|}{$\begin{array}{l}\text { Panel C: Zero-Inflated } \\
\text { Poisson }\end{array}$} & \multicolumn{2}{|c|}{$\begin{array}{c}\text { Panel D: Zero-Inflated } \\
\text { Negative Binomial }\end{array}$} \\
\hline & $\begin{array}{c}\text { Coefficient } \\
(\boldsymbol{\beta})\end{array}$ & $\begin{array}{c}P \\
\text { value }\end{array}$ & $\begin{array}{l}\text { Coefficient } \\
(\beta)\end{array}$ & $P$ value & Coefficient ( $\beta$ ) & $P$ value & Coefficient ( $\beta$ ) & $P$ value \\
\hline Intercept & 1.192 & .108 & 1.174 & .133 & $1.391 *$ & .071 & $1.391 \%$ & .075 \\
\hline INSIDERS & $-0.025 * * *$ & .002 & $-0.026 * * *$ & .003 & $-0.024 * * *$ & .003 & $-0.026 * * *$ & .003 \\
\hline INSTL & $-0.048^{*}$ & .050 & $-0.048^{*}$ & .064 & $-0.046^{*}$ & .067 & $-0.046^{*}$ & .067 \\
\hline BETA & $1.696 * *$ & .037 & $1.713 * *$ & .046 & $1.779 * *$ & .039 & $1.779 * *$ & .039 \\
\hline$S q B E T A^{\mathrm{a}}$ & $-0.757 * *$ & .040 & $-0.762 * *$ & .049 & $-0.792 * *$ & .041 & $-0.792 * *$ & .041 \\
\hline$D E B T$ & $0.155^{* * *}$ & .000 & $0.156^{* * *}$ & .001 & $0.138^{* * *}$ & .000 & $0.138 * * *$ & .001 \\
\hline$F C F$ & $-0.0004 * * *$ & .001 & $-0.0004 * * *$ & .000 & $-0.0004 * * *$ & .000 & $-0.0004 * * *$ & .000 \\
\hline $\operatorname{LnASSETS}^{\mathrm{b}}$ & $-0.203 * * *$ & .007 & $-0.203 * *$ & .012 & $-0.206^{* * *}$ & .009 & $-0.206^{* * *}$ & .009 \\
\hline CAPEX & $-3.934 *$ & .091 & -3.680 & .135 & -3.714 & .131 & -3.714 & .132 \\
\hline Number of observations & \multicolumn{2}{|l|}{336} & \multicolumn{2}{|l|}{336} & \multicolumn{2}{|l|}{336} & \multicolumn{2}{|c|}{336} \\
\hline Log likelihood (Restricted & \multicolumn{2}{|c|}{-276.106} & \multirow{2}{*}{\multicolumn{2}{|c|}{$\begin{array}{l}-275.166 \\
(-300.340)\end{array}$}} & \multirow{2}{*}{\multicolumn{2}{|c|}{$\begin{array}{l}-274.998 \\
(-300638)\end{array}$}} & \\
\hline Log likelihood) & \multicolumn{2}{|c|}{$(-309.106)$} & & & & & \multicolumn{2}{|c|}{$(-300.222)$} \\
\hline LR statistic (df) & \multicolumn{2}{|c|}{$66.00 * * *(8)$} & \multicolumn{2}{|c|}{$55.35 * * *(8)$} & \multicolumn{2}{|c|}{$51.28 * * *(8)$} & \multicolumn{2}{|c|}{$50.45 * * *(8)$} \\
\hline Probability (LR stat) & \multicolumn{2}{|c|}{.0000} & \multicolumn{2}{|c|}{.0000} & \multicolumn{2}{|c|}{.0000} & \multicolumn{2}{|c|}{.0000} \\
\hline LR Index (Pseudo R ${ }^{2}$ ) & \multicolumn{2}{|l|}{0.1068} & \multicolumn{2}{|c|}{0.0838} & \multicolumn{2}{|l|}{0.0853} & \multirow{2}{*}{\multicolumn{2}{|c|}{$\begin{array}{c}0.0840 \\
0.00047(.998)\end{array}$}} \\
\hline $\begin{array}{l}\text { Alpha Dispersion Parameter } \\
\text { (P value) }\end{array}$ & NA & & \multicolumn{2}{|c|}{$0.248(.226)$} & \multicolumn{2}{|l|}{ NA } & & \\
\hline Vuong statistic & \multicolumn{2}{|l|}{ NA } & \multicolumn{2}{|l|}{ NA } & \multicolumn{2}{|l|}{0.67} & \multicolumn{2}{|c|}{3.58} \\
\hline
\end{tabular}

$*, * *$ and $* * *$ indicate that coefficient is significant, respectively, at $10 \%, 5 \%$ and $1 \%$ thresholds.

${ }^{\text {a }} \mathrm{Sq}$ indicates a quadratic transformation ; ${ }^{\mathrm{b}} \mathrm{Ln}$ indicates a Logarithmic transformation.

Results reported in Table 4 highlight that both institutional and insider ownership have a significant negative influence on number of additional blockholders. In fact, institutional investors may serve as a substitute for blockholders in monitoring firm management thanks to their large material resources and highly-developed competences (Grossman and Hart, 1980; McConnell and Servaes, 1990; Gillan and Starks, 2007). Besides, blockholders are less prone to extract private benefits of control in presence of affluent institutional investors (Barclay and Holderness, 1989). They are thus less inclined to either enlarge their shareholding or to enter such a firm. This result is consistent with hypothesis 1 . Similarly, directors and managers who hold shares in their firms are likely to closely run firm management and to lock on control (Shleifer and Vishny, 1986; McConnell and Servaes, 1990). Insiders can thus constitute eminent rivals for blockholders. Moreover, blockholders can no longer extract private benefits of control; whenever insiders detain large stakes (Grossman and Hart, 1980; Barclay and Holderness, 1989). Insiders would also entrench themselves to take out potential control benefits. Willingness of blockholders to invest in such a firm will decline; which is in line with hypothesis 2.

With regard to firms' characteristics, our first finding shows that risk level exerts a significant impact on our dependent variable. As far as level of risk rises, blockholders become more tempted to increase their ownership in order to enjoy higher returns (Sharpe, 1964; Lintner, 1965; Ross, 1976); and eventually to accrue larger benefits (Bowman, 1980; Miller and Bromiley, 1990). Increase of their shareholding might be also due to managerial incentives. In fact, they ought to enlarge their stakes to achieve absolute control; and hence to cope efficiently with risks (Demsetz, 1983; Demsetz and Lehn, 1985). Such finding provides support to hypothesis 3a. Remaining in full 
control allows blockholders not only to better monitoring firm; but also to preserve their own interests and even siphon off higher private benefits (Bebchuk, 1999). However, when shifting to quadratic relationship, coefficient associated with quadratic effect is significantly negative. Such a result suggests that excessive levels of risk discourage blockholders to get larger stakes. Their incentives to diversify their portfolios might be stronger when costs and drawbacks of risk are excessively high (Markowitz, 1952; Merton, 1972; Hu and Izumida, 2008). This result is consistent with hypothesis $3 \mathrm{~b}$. This pattern of relationship suggests that accordingly to level of risk, blockholders are willing or not to enter or exit a firm. Their rational decision is based upon a trade-off between benefits and costs of risk. Table 4 also provides evidence that increase in number of blockholders is positively influenced by firm leverage. This finding is not in line with hypothesis 4; but complies instead with results of Harris and Raviv (1988) as well as Stulz (1990). According to these authors, blockholders are willing to concentrate their ownership to inflate their voting power and to better monitor firm management in levered firms. Blockholders would rather use debt than issue equity in order not to preserve level of their ownership rights (Jensen and Meckling, 1976). Moreover, creditors are recognized to be efficient monitors. Perhaps, their presence incites investors to trust levered firms and to enlarge their stakes. Furthermore, shareholding concentration ultimately allows blockholders to enjoy larger private benefits (Carvalhal-da-Silva and Subrahmanyam, 2007; Albuquerque and Schroth, 2010).

Results reported in Table 4 exhibit that level of free cash flow has a significant negative impact on number of additional blockholder. According to adverse selection hypothesis, when level of free cash flow is high, there are a lot of shareholders that own, investigate, and deal with information (Black, 1992; Hartzel and Starks, 2003). Agency problems and interests conflicts are thus expected to be more severe and acute. These firms are difficult to monitor; which deter shareholders to invest larger stakes. Such a result is consistent with hypothesis 5. Likewise, empirical findings show that firm size has a significant negative influence on dependent variable. This result suggests that large shareholders are not incited to join list of blockholders even though they can enjoy economies of scale in monitoring big firms. Perhaps, agency conflicts are more intense and market monitoring is powerful. Blockholders cannot easily extract private benefits of control; hence it is not worth enlarging ones holdings. Additionally, financial constraints likely deter shareholders from acquiring significant stakes in larger firms (Demsetz and Lehn, 1985; Faccio and Lang, 2002). Similarly, blockholders are dissuaded to invest larger stakes in firms spending larger amounts in capital expenditures to afford new growth opportunities. For instance, these expenses are discretionary and intangible; and hence hard to control. Blockholders cannot afford valuable private benefits of control in such firms. Besides, shareholders, mainly minority ones, are appealed to firms with greater opportunities as they seek future, rather than immediate, revenues. These shareholders are not actually inclined to sell their shares. Therefore, larger shareholders cannot increase their ownership anymore. However, this result should be considered with care, since it is only valid under Poisson specification; and is no longer verified through three other applied models.

\section{CONCLUSION}

This paper addresses the following crucial question: What are the determinants of increase in number of blockholders? Data on corporate governance and financial characteristics for 156 Canadian listed firms, during 2008-2010, are used to answer above mentioned question. More specifically, we investigate influence of ownership structure, firm's risk, debt, liquidity and size on number of additional blockholders. Due to discreteness of our dependent variable, we apply four Count Data models which provide highly robust results.

On one hand, empirical results show that presence of institutional shareholders and insiders deters blockholders to enter a firm. These investors are in fact recognized to be serious rivals for blockholders and do not let them extract higher private benefits as they used to do. Similarly, this study provides evidence that excessive high levels of risk, firm size, capital expenditures as well as free cash flow dissuade shareholders from getting larger stakes. Perhaps, such firms are more difficult monitoring; which implies more intense interests' conflicts. On the other hand, moderate levels of risk and firm leverage encourage shareholders to join blockholders' list. Firm leverage is a hard mechanism that allows alleviating agency problems and enhancing firm performance. Investors should incur risks and invest in new opportunities in order to promote firm profitability. But when exceeding a certain threshold costs and drawbacks of risks become unbearable and hence fall of firm performance. Shareholders become more prone to diversify their portfolios. 
The findings of this study have at least two major implications. First of all, this research helps understanding blockholders' behavior and reveals main factors that might incite investors to concentrate their ownership. Our results highlight what might influence decision of a blockholder to enter or exit a firm. For instance, a blockholder is eager to invest in firms that he can well control and that enable him to accrue higher revenues. He is conversely reluctant to acquire large stakes in firms that need more deployed efforts to be governed; and hence excessive monitoring costs that would outweigh potential benefits. Therefore, firms, mainly smaller and publicly traded ones, must realize that access to financing from blockholders is not evident. Secondly, study sheds light on endogeneity and dynamic nature of ownership structure. In contrast to previous studies, mostly devoted to widely dispersed ownership firms, Canada provides useful information for economies with concentrated ownership and approves of endogeneity of block holding.

This study also offers several directions for future research. In particular, this study finds out determinants of number of additional blockholders without making inferences about size of stakes. Perhaps, not all blockholders have similar attitudes and behavior. Their preferences and decisions to enter or exit heavily depend on width of their shareholdings. This issue deserves further analysis. This research can be also extended by considering dynamic endogeneity between block ownership and firms' financial characteristics, such as risk. Likewise, it is worth investigating, through simultaneous equations modeling, interdependence between number of large shareholders and other ownership structure variables.

\section{AUTHOR INFORMATION}

Malek Saihi, Professor of Finance, Faculty of Economics and Management of Tunis, Tunisia. E-mail: malek.saihi.1@ulaval.ca

Amel Belanes, Associate Professor of Finance, High Institute of Management of Tunis, Tunisia. E-mail: amel_bns@yahoo.fr (Corresponding author)

\section{REFERENCES}

1. Albuquerque, R. \& Schroth, E. (2010). Quantifying private benefits of control from a structural model of block trades. Journal of Financial Economics, 96(1), 33-55.

2. Baozhi, Q. (2004). What determines corporate ownership concentration around the world? Advances in Financial Economics, 9, 221-46.

3. Barclay, M.J. \& Holderness, C. (1989). The private benefits from control of public corporations. Journal of Financial Economics, 5, 371-95.

4. Bebchuk, L.A. (1999). A rent-protection theory of corporate ownership and control. NBER Working Paper no.7203. National Bureau of Economic Research, Inc.

5. Berle, A. \& Means, G. (1932). The modern corporation and private property. Harcourt, Brace, \& World, New York.

6. Bethel, J., Liebeskind, J.P. \& Opler, T. (1998). Block share purchases and corporate performance. Journal of Finance, 53, 650-53.

7. Black, B. (1992). Agents watching agents: The promise of institutional investor voice. UCLA Law Review, 39, 811-93.

8. Bowman, E.H. (1980). A Risk/Return Paradox for Strategic Management. Sloan Management Review, 21(3), 17-31.

9. Bozec, Y. \& Laurin, C. (2008). Large shareholder entrenchment and performance: empirical evidence from Canada. Journal of Business Finance \& Accounting, 35(1-2), 25-49.

10. Cameron, A.C. \& Trivedi, P.K. (1998). Regressions analysis of count data. Cambridge: Cambridge University Press.

11. Carvalhal-da-Silva, A.L. \& Subrahmanyam, A. (2007). Dual-class premium, corporate governance, and the mandatory bid rule: evidence from the Brazilian stock market. Journal of Corporate Finance, 13, 1-24.

12. Cincera, M. (1997). Patents, R\&D, and technological spillovers at the firm level: some evidence from econometric count models for panel data. Journal of Applied Econometrics, 12, 265-280. 
13. Demsetz, H. \& Lehn, K. (1985). The structure of corporate ownership: causes and consequences. Journal of Political Economy, 93(6), 155-77.

14. Demsetz, H. (1983). The structure of ownership and the theory of the firm. Journal of Law and Economics, 26, 375-90.

15. Denis, D.J. \& Sarin, A. (1999). Ownership and board structure in publicly traded corporations. Journal of Financial Economics, 52, 187-224.

16. Faccio, M. \& Lang, H.P. (2002). The ultimate ownership of Western European corporations. Journal of Financial Economics, 65(3), 365-95.

17. Faria, A., Fenn, P. \& Bruce, A. (2003). A count data model of technology Adoption. Journal of Technology Transfer, 28, 63-79.

18. Francis D. (2008), Who owns Canada now? Old money. New Money and the Future of Canadian Business. Harper Collins Canada.

19. Gadhoum Y. (2006). Power of ultimate controlling owners: a survey of Canadian landscape. Journal of Management Governance, 10, 179-204.

20. Gillan, S.L. \& Starks, L.T. (2007). The evolution of shareholder activism in the United States. Journal of Applied Corporate Finance, 19, 55-73.

21. Glosten, L.R. \& Milgrom, P.R. (1985). Bid, ask and transaction prices in a specialist market with heterogeneously informed traders. Journal of Financial Economics, 14, 71-100.

22. Grossman, S.J. \& Hart, O.D. (1980). Takeover bids, the free rider problem and the theory of the corporation. Bell Journal of Economics, 11, 42-64.

23. Grossman, S.J. \& Stiglitz, J.E. (1980). On the impossibility of informationally efficient markets. American Economic Review, 80, 393-408.

24. Harris, M. \& Raviv, A. (1988). Corporate control contests and capital structure. Journal of Financial Economics, 20, 55-86.

25. Hart, O. \& Moore, J. (1995). Debt and seniority: An analysis of the role of hard claims in constraining management. American Economic Review, 85, 567-85.

26. Hartzell, J. \& Starks, L.T. (2003). Institutional investors and executive compensation. Journal of Finance, $58,2351-74$.

27. Holderness, C.G. \& Sheehan, D.P. (1988). The role of majority shareholders in publicly held corporations. Journal of Financial Economics, 20(41), 317-46.

28. Hu, Y. \& Izumida, S. (2008). Ownership concentration and corporate performance: a Causal analysis with Japanese panel data. Corporate Governance: An International Review, 16, 342-58.

29. Jensen, M. (1986). Agency costs of free cash flow, corporate finance, and takeovers. American Economic Review, 76, 323-29.

30. Jensen, M.C. \& Meckling, W.H. (1976). Theory of the firm: managerial behavior, agency costs, and ownership structure. Journal of Financial Economics, 3(4), 305-60.

31. La Porta, R., Lopez-de-silanes, F. \& Shleifer, A. (1999). Corporate ownership around the world. Journal of Finance, 54(2), 471-517.

32. Landry, R., Amara, N. \& Saïhi, M. (2007). Patenting and spin-off creation by Canadian researchers in engineering and life sciences. The Journal of Technology Transfer, 32(3), 217-49.

33. Lintner, J. (1965). The valuation of risk assets and the selection of risky investments in stock portfolios and capital budgets. Review of Economics and Statistics, 47(1), 13-37.

34. Long, J.S. (1997). Regression Models for Categorical and Limited Dependent Variables. Advanced Quantitative Techniques in the Social Sciences. Sage Publications: Thousand Oaks, CA.

35. Markowitz, H.M. (1952). Portfolio selection. The Journal of Finance, 7(1), 77-91.

36. McConnell, J.J. \& Servaes, H. (1990). Additional evidence on equity ownership and corporate value. Journal of Financial Economics, 27(2), 595-612.

37. Merton, R. (1972). An analytic derivation of the efficient portfolio frontier. Journal of Financial and Quantitative Analysis, 7, 1851-72.

38. Miller, K. \& Bromiley, P. (1990). Strategic risk and corporate performance: an analysis of alternative risk measures. Academy of Management Journal, 33(4), 756-79.

39. Morck R., Stangeland D. A. \& Yeung B. (2000). Inherited wealth, corporate control and economic growth: the Canadian disease? In R. Morck (Eds.), Concentrated Corporate Ownership (pp. 319-69). National Bureau of Economic Research. 
40. Mueller, E. (2008). Benefits of control, capital structure and company growth. Applied Economics, 40(21), 2721-34.

41. Naylor, R.T. (1975). History of Canadian Business 1867-1914, James Lorimer \& Co. Toronto.

42. Ross, S. (1976). The arbitrage theory of capital asset pricing. Journal of Economic Theory, 13, 341-60.

43. Sharpe, W.F. (1964). Capital asset prices: a theory of market equilibrium under conditions of risk. Journal of Finance, 19(3), 425-42.

44. Shleifer, A. \& Vishny, R.W. (1986). Large shareholders and corporate control. Journal of Political Economy, 94(3), 461-88.

45. Stulz, R. (1990). Managerial discretion and optimal financial policies. Journal of Financial Economics, 26, 3-27.

46. Valsan, C. (2007). A Canadian corporate ownership survey. The European Journal of Comparative Economics, 7(2), 285-306.

47. Yip, K.C.H. \& Yau, K.K.W. (2005). On modeling claim frequency data in general insurance with extra zeros. Insurance: Mathematics and Economics, 36(2), 153-63. 


\section{$\underline{\text { NOTES }}$}

